\title{
Mezinárodní výzkum kompetencí dospělých PIAAC: hlavní zjištění a implikace pro vzdělávací politiku
}

\author{
Jana Straková a ${ }^{1}$, Arnošt Veselý ${ }^{\mathrm{b}}$ \\ a Univerzita Karlova v Praze, Pedagogická fakulta, Ústav výzkumu a rozvoje vzdělávání \\ ${ }^{\mathrm{b}}$ Univerzita Karlova v Praze, Fakulta sociálních věd, Institut sociologických studií
}

Redakci zasláno 3. 2. 2015 / upravená verze obdržena 19. 3. 2015 /

k uveřejnění přijato 23. 3. 2015

\begin{abstract}
Abstrakt: Cílem této přehledové studie je představit výzkum PIAAC, shrnout základní zjištění z tohoto výzkumu z hlediska České republiky a diskutovat možné implikace pro vzdělávací politiku. Zároveň rozebíráme, jak výsledky výzkumu PIAAC doplňují poznatky získané z výzkumu PISA, TIMSS a dalších. Klademe si přitom otázku, zda (a co) přináší nad rámec těchto výzkumů. V první části studie je popsána metodologie a základní charakteristika výzkumu PIAAC. Ve druhé části popisujeme výsledky českých dospělých v mezinárodním srovnání. Ve třetí části vybíráme některá zásadní zjištění výzkumu PIAAC. V závěrečné části pak diskutujeme implikace těchto zjištění pro nastavení vzdělávací politiky. Výzkum PIAAC potvrdil některá zjištění z předcházejících výzkumů PISA a TIMSS, např́klad vysokou míru podmíněnosti kompetencí socioekonomickým statusem $\mathrm{v}$ České republice. Jiné závěry z těchto výzkumů ovšem nepotvrdil. Ukázalo se např́íklad, že výsledky mladých Češek a Čechů ve věku 16-25 let (kam spadá kohorta z výzkumů TIMSS 2007 a PISA 2009) jsou spíše nadprůměrné. Výzkum PIAAC je důležitým a nepostradatelným doplňkem výzkumů, zkoumajících kompetence žákovské populace. Ačkoli s výsledky z výzkumů PISA nebo TIMSS se často pracuje jako s definitivním ukazatelem gramotnosti a lidského kapitálu dané země, výzkum PIAAC ukázal, že v 15 letech zdaleka nejsou kompetence definitivně zformovány.
\end{abstract}

Klíčová slova: PIAAC, funkční gramotnost, vzdělávací politika

\section{Základní informace o výzkumu kompetencí dospělých PIAAC}

Mezinárodní výzkum kompetencí ${ }^{2}$ dospělých - PIAAC (Programme for the International Assessment of Adult Competencies) je součástí významné

1 Práce autorky na textu byla podpořena z projektu GA ČR: Vztahy mezi dovednostmi, vzděláváním a výsledky na trhu práce: longitudinální studie (číslo P402/12/G130).

2 V tomto textu se opakovaně zmiňujeme o gramotnostech (literacies), kompetencích (competencies) a dovednostech (skills). Tyto výrazy speciálně nedefinujeme a používáme je jako 
strategie OECD zaměřené na rozvoj a aktivaci dovedností a jejich efektivní využívání (OECD Skills Strategy). Strategie reaguje na skutečnost, že v posledních desetiletích dochází k velkým změnám, které ovlivňují řadu aspektů pracovního i soukromého života obyvatel vyspělých zemí. Mění se způsob práce i dílčí pracovní činnosti, způsob soukromé i úřední komunikace, nakupování, trávení volného času. Statistiky ukazují, že roste počet pracovních míst s vyššími nároky na vzdělání a flexibilitu. Pracující se stále častěji musejí vyrovnávat s radikálními změnami pracovní náplně danými restrukturalizací pracovišt' a s nečekanými změnami pracovního trhu, které jsou provázeny nutností často měnit zaměstnání. S tím souvisí potřeba držet krok s novými technologiemi a materiály a učit se novým, stále složitějším dovednostem.

OECD Skills Strategy vychází z toho, že vzdělávací systémy musí své občany vybavit takovými dovednostmi, které jim umožní dostát nárokům života v moderní společnosti. Zdůrazňuje však také, že se pracovní trh musí naučit efektivně využívat dovedností, které jsou k dispozici. K tomu často nedochází nejen $\mathrm{z}$ důvodů nezaměstnanosti, ale též z toho důvodu, že jsou pracovníkům přidělovány špatné pracovní úkoly. Proto výzkum PIAAC, na rozdíl od předcházejících výzkumů vědomostí a dovedností dospělých, zkoumal nejen míru osvojení vědomostí a dovedností potřebných pro úspěch $v$ běžném životě i na pracovním trhu, ale sledoval i jejich využívání v běžném životě a v práci.

V možnostech tohoto textu není představit celou šiŕi výsledků výzkumu a jejich podnětů pro veřejnou politiku. Vzhledem k tomu, že je zaměřen na dospělou populaci, mapuje souvislost vědomostí a dovedností nejen s počátečním vzděláváním, ale též s dalším vzděláváním, uplatněním na trhu práce a v občanském životě. Výzkum tedy přináší řadu podnětů pro sociální politiku a politiku zaměstnanosti. Výsledkům týkajícím se těchto oblastí se v tomto textu vůbec nevěnujeme.

Text podává přehled hlavních zjištění, která se nějakým zpưsobem týkají počátečního vzdělávání, dává je do souvislosti s již dříve uskutečněnými

synonyma, nebot' tak figurují v dokumentech týkajících se výzkumu PIAAC (výzkum je paralelně nazýván Programme for International Assessment of Adult Competencies a Survey of Adult Skills, OECD, 2013a). Terminologický přístup OECD je obecně poněkud matoucí. Zatímco publikace Defining and Selecting Competencies (Rychen \& Salganik, 2001), která sloužila jako teoretický podklad pro výzkum PISA, precizně definovala pojem kompetence, výzkum PISA pracuje s koncepty matematické, čtenářské a přírodovědné gramotnosti (např OECD, 2013b). V názvu výzkumu PIAAC sice figurují kompetence, ale čím dál častěji je na něj odkazováno jako na výzkum dovedností. 
výzkumy a diskutuje jejich implikace pro vzdělávací politiku. Text je strukturován následujícím způsobem: V první části představujeme metodologii výzkumu PIAAC. V druhé a nejrozsáhlejší části analyzujeme výsledky České republiky v mezinárodním srovnání. Souvislosti mezi kompetencemi a dalšími proměnnými zpravidla ilustrujeme na čtenářských kompetencích. Čtenářské kompetence jsme volili z toho důvodu, že jsou základní podmínkou pro další vzdělávání a učení. Souvislosti s ostatními kompetencemi jsou ve všech př́ípadech velmi podobné. Konečně v závěrečné části diskutujeme přínosy tohoto výzkumu a implikace pro vzdělávací politiku v ČR.

\section{Metodologie výzkumu PIAAC}

Mezinárodní výzkum kompetencí dospělých - PIAAC hodnotil úroveň čtenářské a numerické gramotnosti a dovednosti řešit problémy v prostředí informačních technologií u osob ve věku 16-65 let. K hodnocení byly použity kognitivní testy a dotazníky, které byly administrovány $\mathrm{v}$ domácnostech proškolenými tazateli.

Všechny tři sledované oblasti byly pro účel výzkumu přesně definovány a vymezeny prostřednictvím hodnoceného obsahu, hodnocených kognitivních strategií a kontextu úloh. $\mathrm{V}$ matematice byl matematický obsah např́iklad vymezen podle matematických oblastí: množství a číslo, rozměr a tvar, zákonitosti, vztahy a změny a data a pravděpodobnost a podle reprezentace matematických informací: předměty a nákresy, čísla a matematické symboly, vizuální zobrazení (např. diagramy, mapy, grafy, tabulky), texty a elektronická zobrazení. Ve čtenářské gramotnosti bylo $\mathrm{v}$ rámci kognitivních strategií například sledováno, do jaké míry dovedou respondenti zjistit a rozpoznat vybrané skutečnosti, integrovat a interpretovat vzájemně související části textu a předložený text hodnotit a reflektovat. Kontexty úloh byly pro všechny oblasti identické: pracovní, osobní, společnost a komunita a vzdělání a školení. Součástí výzkumu bylo rovněž hodnocení základních čtenářských dovedností, jehož cílem bylo odhalit specifické problémy respondentů s nízkou úrovní čtenářské gramotnosti a které bylo administrováno respondentům, kteří nezvládli úvodní testový blok s několika jednoduchými úlohami (blíže o koncepci hodnocení viz OECD, 2013c; Straková \& Veselý, 2013).

Ke zpracování výsledků za jednotlivé hodnocené oblasti byla použita teorie odpovědi na položku (Item Response Theory), která je založena na vztahu mezi pravděpodobností správného vyřešení úlohy, zdatností respondenta 
(ability) a obtížností úlohy. Umožňuje aplikaci neúplného testového designu, při kterém různí respondenti řeší různé sady úloh, nebot' latentní proměnná, která udává zdatnost respondenta $\mathrm{v}$ dané oblasti, není striktně vázána na konkrétní test (danou sadu úloh). Tato metodologie je v mezinárodních výzkumech vědomostí a dovedností běžně využívána, nebot' umožňuje pokrýt podstatně širší rozsah vědomostí a dovedností, než by bylo možno prostřednictvím jednoho testu, který by byl všem respondentům společný. Zároveň umožňuje měřit na stejné škále výsledky v jednotlivých cyklech a prímo měřit přírůstky.

Výzkum PIAAC byl ovšem prvním mezinárodním měřením vědomostí a dovedností, ve kterém byly testové úlohy administrovány prostřednictvím počítačů a byly počítačem rovněž vyhodnocovány bez zapojení externích hodnotitelů. Okamžité vyhodnocování odpovědí umožnilo v oblasti matematické a čtenářské gramotnostiadaptivní testování, ve kterém byla obtížnost zadávaných úloh přizpůsobena kognitivním schopnostem respondenta. Toto hodnocení bylo tím pádem přesnější než dosud uplatňovaný model, při kterém řešili všichni respondenti úlohy stejné obtížnosti. Pro respondenty, kteří nebyli schopni absolvovat testování na počítači, byly k dispozici tištěné testové sešity, které obsahovaly úlohy z numerické a čtenářské gramotnosti.

V oblasti čtenářské a numerické gramotnosti navázal PIAAC na výzkumy IALS (International Adult Literacy Survey), který proběhl v ČR v roce 1998, a ALL (Adult Literacy and Lifeskills Survey), který proběhl v letech 2003 až 2008 a kterého se ČR nezúčastnila. Koncepce testu čtenářské gramotnosti umožnila přímé srovnání výsledků výzkumu PIAAC a IALS.

Kromě testů byly respondentům administrovány rovněž dotazníky, které se zaměřovaly na zjištóování základních demografických charakteristik a rodinného zázemí respondentů, počáteční a další vzdělávání, zaměstnanecký status a zkušenosti na trhu práce, společenské angažovanosti a zdravotního stavu a využívání rozmanitých dovedností v situacích běžného života a zaměstnání. Výzkum byl realizován v domácnostech na pravděpodobnostním výběru respondentů. $\mathrm{V}$ ČR byly nejprve náhodně vybrány volební okrsky, ve volebních okrscích náhodně adresy, na adresách náhodně domácnosti (v př́ípadě více domácností na jedné adrese) a dále náhodně respondenti ve věku 16-65 let. Povinný počet respondentů na jednu zúčastněnou zemi činil 5000, ČR provedla nadvýběr 1000 respondentů ve věku 16-29 let. Do výzkumu se aktivně zapojilo 6102 respondentů. Návratnost činila $66 \%$. 
Na mezinárodní úrovni byl výzkum PIAAC řízen Organizací pro hospodářskou spolupráci a rozvoj. Vývoj metodologie a výzkumných nástrojů zajišt'ovalo mezinárodní konsorcium výzkumných institucí, v jehož čele stál Education Testing Service ze Spojených států. Sběr dat, kterého se spolu s ČR zúčastnilo celkem 24 zemí, proběhl na přelomu roku 2011 a 2012. Výsledky byly zveřejněny 8. 10. 2013. V ČR výzkum zajištoval Ústav pro informace ve vzdělávání, po jeho zrušení v roce 2011 Dům zahraniční spolupráce. Šetření v domácnostech provedla společnost SC\&C. Na výběr respondentů i vlastní realizaci výzkumu byly aplikovány náročné standardy (PIAAC Technical Standards and Guidelines) a jejich dodržování muselo být zúčastněnými zeměmi pečlivě dokladováno a bylo přísně kontrolováno. Výsledný datový soubor je tedy velice kvalitní.

\section{Klíčová zjištění výzkumu PIAAC}

Tento oddíl prezentuje vybrané výsledky výzkumu, které jsou autory považovány za nejdůležitější z hlediska vzdělávací politiky. Nezabýváme se aspekty přechodu na pracovní trh a pracovním uplatněním respondentů ani využitím kompetencí v zaměstnání a běžném životě.

\subsection{Celkové výsledky a jejich rozložení}

Tabulka 1 ukazuje celkové výsledky výzkumu PIAAC. Ve čtenářské a numerické gramotnosti jsou výsledky prezentovány na škále o rozsahu 0-500 bodů. Jak bylo uvedeno výše, pro tyto oblasti existovala k elektronickému hodnocení písemná alternativa a výsledky byly zpracovány na stejné škále. Průměrný výsledek tedy bylo možno odhadnout pro celou testovanou populaci.

$\mathrm{V}$ př́ipadě řešení problémů $\mathrm{v}$ oblasti informačních technologií byla situace odlišná, nebot' toto hodnocení bylo administrováno pouze elektronicky a v jednotlivých zemích se do něj zapojily různě velké skupiny respondentů. V rámci zemí OECD uvedlo v průměru 9,3\% dospělých, že nemají žádnou předchozí zkušenost s počítačem, v ČR bylo těchto respondentů 10,3 \%. Dalších 4,9\% dospělých nemělo základní počítačové dovednosti, tedy neprošlo vstupním testem počítačových dovedností (v ČR 2,2 \%). 10,2 \% dospělých se rozhodlo pracovat s písemným testem, aniž by psali vstupní test počítačových dovedností (v ČR $12 \%$ respondentů). Proto byly výsledky porovnávány nikoli prostřednictvím průměrného výsledku, ale prostřednictvím podílu dospělých, kteří prokázali vysokou způsobilost (tedy dosáhli určitého předem definovaného výsledku). 
Tabulka 1 ukazuje, že dospělí z Finska, Nizozemska, Norska a Švédska dosáhli ve všech sledovaných oblastech nadprůměrných výsledků. Irsko, Polsko a Spojené státy mají naopak ve všech třech sledovaných oblastech podprůměrné výsledky. Itálie a Španělsko mají podprůměrné výsledky ve čtenářské a numerické gramotnosti a neúčastnily se testování v oblasti řešení problémů (tato oblast byla volitelná). Česká republika dosáhla nadprůměrného výsledku v numerické gramotnosti a průměrného výsledku ve čtenářské gramotnosti a v oblasti řešení problémů.

Při pohledu na celkové výsledky je zřejmé, že mezi zúčastněnými zeměmi obecně nejsou velké rozdíly. Značné rozdíly však můžeme pozorovat v rámci jednotlivých zemí. Česká republika se může pochlubit relativně malými rozdíly mezi dospělými s nejlepším a nejhorším výsledkem ve čtenářské a numerické gramotnosti. $V$ této souvislosti je důležitá zejména vysoká hodnota 5. percentilu ve čtenářské a numerické gramotnosti (jedna z nejvyšších v mezinárodním srovnání). Tato hodnota ukazuje, že se v České republice daří udržovat na relativně dobré úrovni čtenářské a numerické dovednosti u skupiny lidí, kteří prokazují nejnižší kompetence, respektive že lidí s velmi špatnými čtenářskými kompetencemi je v ČR málo.

\subsection{Vývoj mezi lety 1998 a 2012}

Srovnání výsledků ve čtenářské gramotnosti ve výzkumech IALS a PIAAC (obrázek 1) ukázalo, že v období 1998-2012 jsou celkové výsledky populace 16-65 v ČR ve čtenářské gramotnosti srovnatelné - průměrný výsledek ve výzkumu PIAAC byl 274 (1,0), ve výzkumu IALS 277 (1,0). V jednotlivých kohortách se však situace změnila. Došlo k markantnímu zhoršení výsledků nejmladší kohorty 16-24 a dále ke zhoršení výsledků kohort 35-44 a 45-54 let. Zároveň se zlepšily výsledky nejstarší kohorty 55-65 let. Srovnáme-li průměrné výsledky jednotlivých kohort ve výzkumech IALS a PIAAC v ČR s průměry zemí, které se zúčastnily obou výzkumů, vidíme, že pokles výsledků v nejmladší populaci zcela kopíruje mezinárodní trendy. Společné většině zemí je také zlepšení výsledků nejstarší kohorty. Naopak z pohledu mezinárodního srovnání se jeví nestandardní zhoršení v českých kohortách 35-44 a 45-54 let. 
Tabulka 1

Celková úroveň čtenářské a numerické gramotnosti a dovednosti řešit problémy v prostředí informačních technologií, PIAAC 2012

\begin{tabular}{|c|c|c|c|}
\hline Země & $\begin{array}{l}\text { Čtenářské dovednosti } \\
\text { (průměrné skóre) }\end{array}$ & $\begin{array}{l}\text { Matematické } \\
\text { dovednosti } \\
\text { (průměrné } \\
\text { skóre) }\end{array}$ & $\begin{array}{c}\text { Řešení problémů } \\
\text { v technologicky } \\
\text { bohatém prostředí } \\
(\%)\end{array}$ \\
\hline Průměr & 273 & 269 & 34 \\
\hline Austrálie & 280 & 268 & 38 \\
\hline Anglie / S. Irsko (VB) & 272 & 262 & 35 \\
\hline Česká republika & 274 & 276 & 33 \\
\hline Dánsko & 271 & 278 & 39 \\
\hline Estonsko & 276 & 273 & 28 \\
\hline Finsko & 288 & 282 & 42 \\
\hline Francie & 262 & 254 & $\mathrm{x}$ \\
\hline Irsko & 267 & 256 & 25 \\
\hline Itálie & 250 & 247 & $\mathrm{x}$ \\
\hline Japonsko & 296 & 288 & 35 \\
\hline Kanada & 273 & 265 & 37 \\
\hline Kypr & 269 & 265 & $\mathrm{x}$ \\
\hline Německo & 270 & 272 & 36 \\
\hline Nizozemsko & 284 & 280 & 42 \\
\hline Norsko & 278 & 278 & 41 \\
\hline Polsko & 267 & 260 & 19 \\
\hline Rakousko & 269 & 275 & 32 \\
\hline Slovensko & 274 & 276 & 26 \\
\hline Spojené státy americké & 270 & 253 & 31 \\
\hline Španělsko & 252 & 246 & $\mathrm{x}$ \\
\hline Švédsko & 279 & 279 & 44 \\
\hline Vlámsko (Belgie) & 275 & 280 & 35 \\
\hline
\end{tabular}

Pozn. Tmavě šedou barvou jsou označeny země, které se umístily významně nad mezinárodním průměrem. Světle šedou barvou jsou označeny země, která se umístily významně pod mezinárodním průměrem. Bílou barvou jsou označeny země, které se významně neliší od mezinárodního průměru. 


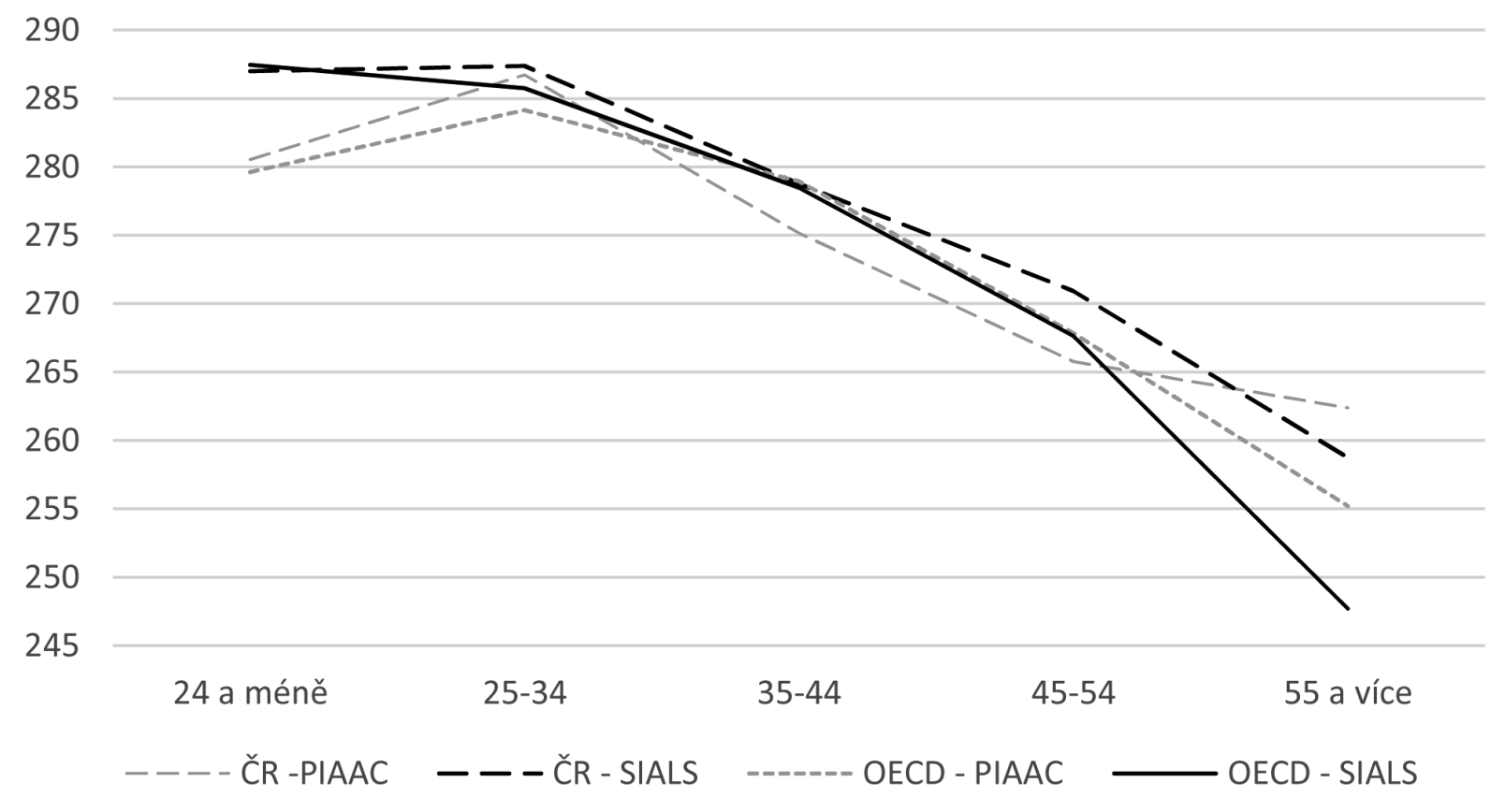

Obrázek 1. Porovnání výsledků ve čtenářské gramotnosti v ČR ve výzkumech PIAAC a IALS podle věkových kohort.

Metodologie výzkumů PIAAC a IALS nám bohužel neumožňuje porovnávat rovněž výsledky $\mathrm{v}$ dalších dvou oblastech: Řešení problémů nebylo součástí IALS a koncept kvantitativní gramotnosti sledované ve výzkumu IALS byl natolik odlišný od konceptu numerické gramotnosti sledované v PIAAC, že nebylo možné vytvořit společnou škálu, na které by bylo možno provést př́imé porovnání. Porovnáme-li relativní pořadí ČR ve vztahu k matematickým dovednostem ve srovnání s ostatními zeměmi, které se zúčastnily obou výzkumů, zjistíme relativní zhoršení v matematických dovednostech a relativní zlepšení v dovednostech čtenářských. Toto „přibližování“ výsledků v matematických a čtenářských dovednostech odpovídá trendům v žákovské populaci.

\subsection{Vývoj kompetencís věkem}

Obrázek 2 ukazuje pro vybrané země výsledky ve čtenářském testu podle věkových kohort. Je z něj zřejmé, že ve většině zemí se vědomosti a dovednosti po 16. roce věku rozvíjejí, kulminují ve středním věku kolem 25-44 let a potom se postupně vytrácejí. Jižní Korea představuje výjimku, zde jsou dovednosti nejmladší populace nejlepší. V Polsku jsou obě nejmladší kohorty na stejné úrovni. Tyto výsledky potvrzují často zmiňované závěry o výrazném zlepšení vzdělávacího systému v těchto dvou zemích. I když ostatní 
země mají průběh kompetencí v tomto smyslu podobný, pozorujeme mezi nimi velké rozdíly ve výsledcích jednotlivých kohort, tedy také v rychlosti ubývání kompetencí s věkem.

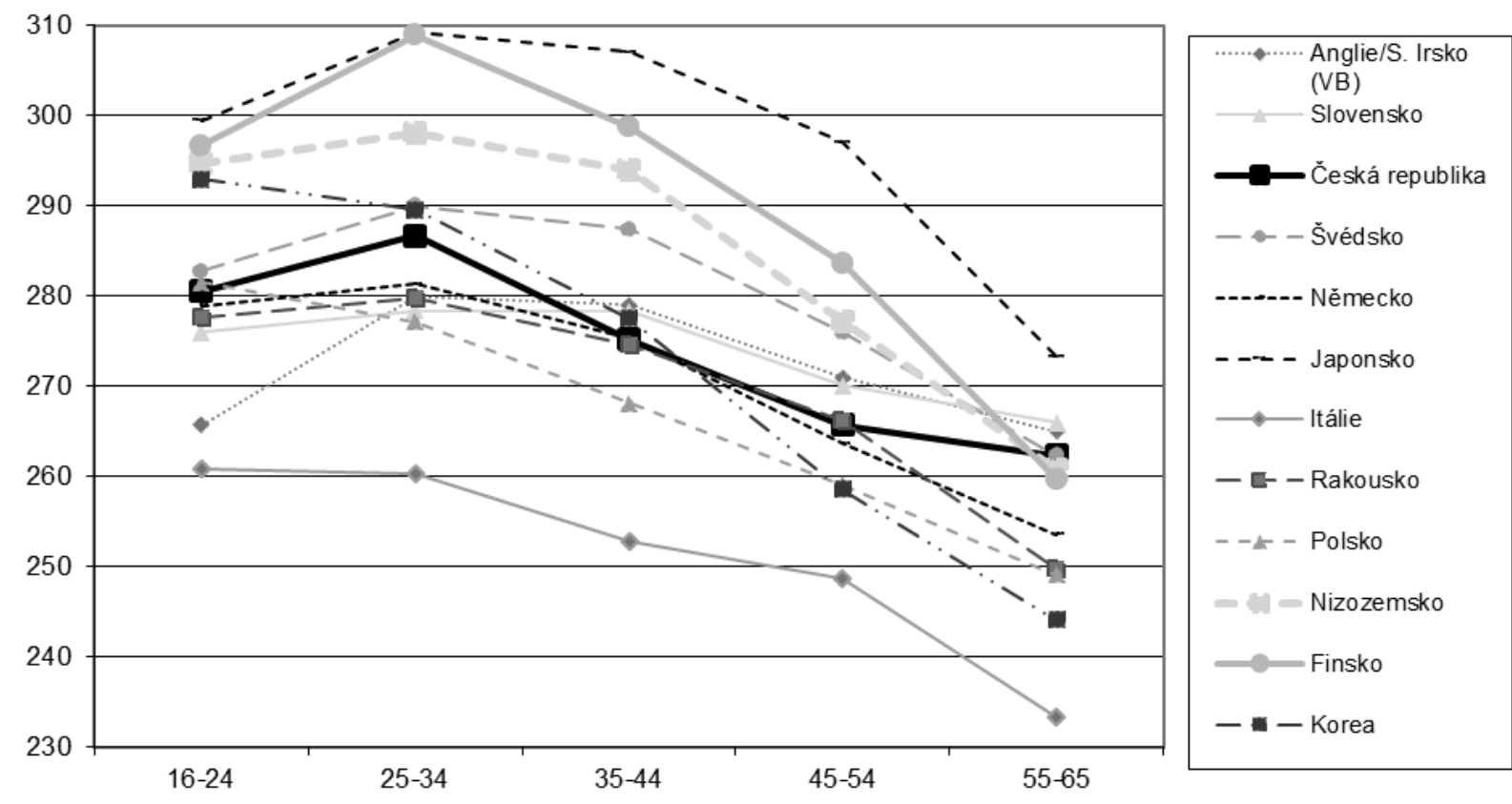

Obrázek 2. Čtenářské kompetence podle věkových kohort, vybrané země.

\subsection{Závislost kompetencí na dosaženém vzdělání}

Výzkum PIAAC ukázal, že se kompetence respondentů odlišují podle dosaženého vzdělání (obrázek 3). I když ve všech zemích platí, že dospělí s vysokoškolským vzděláním si vedli v testu lépe než dospělí se středoškolským vzděláním a ti lépe než respondenti se vzděláním základním, nejsou rozdíly mezi jednotlivými kategoriemi všude stejně velké. Česká republika patří k zemím se spíše nižšími rozdíly mezi jednotlivými vzdělanostními kategoriemi, přičemž pozorujeme větší rozdíly mezi vzděláním vysokoškolským a středoškolským než mezi vzděláním středoškolským a základním. 


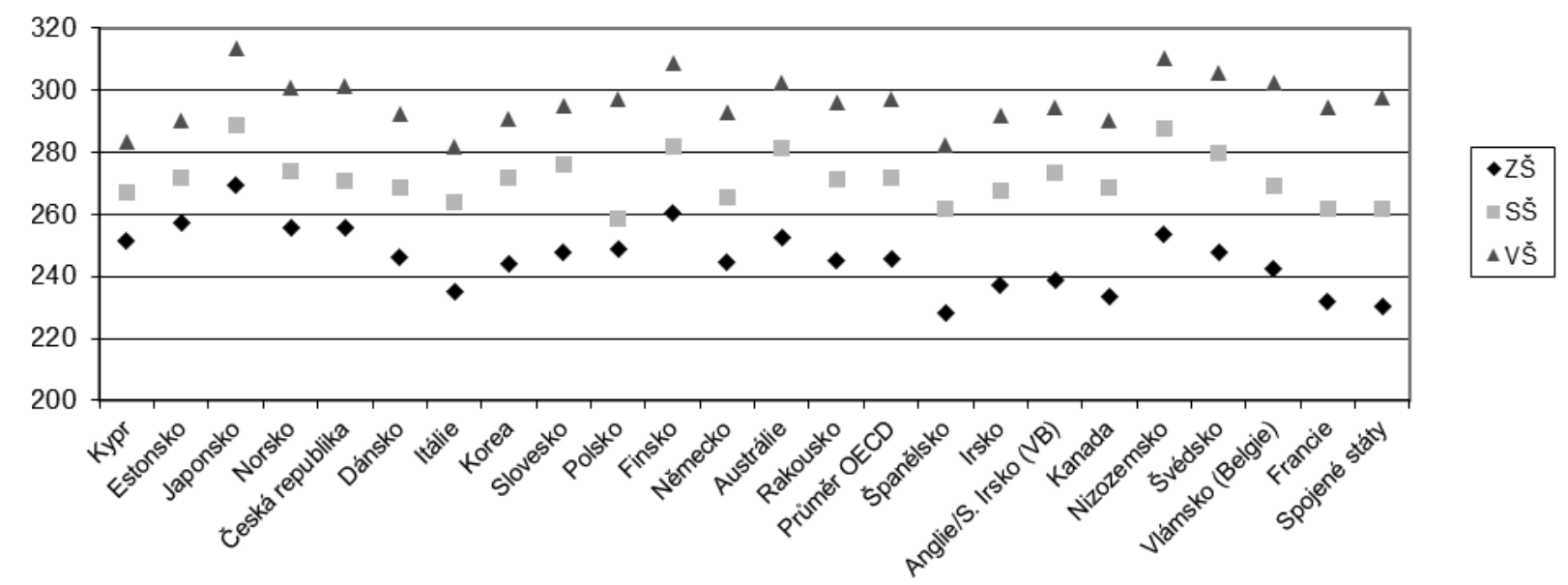

Obrázek 3. Čtenářské kompetence podle nejvyššího dosažného vzdělání.

\subsection{Závislost kompetencí na rodinném zázemí}

Výzkumy v žákovské populaci opakovaně ukazují relativně silnou závislost výsledků vzdělávání na rodinném zázemí. Obrázek 4 ukazuje rozdíly ve čtenářských kompetencích mezi dospělými, jejichž rodiče nedosáhli středoškolského vzdělání, dosáhli středoškolského vzdělání a dosáhli vysokoškolského vzdělání. Z grafu je zřejmé, že Česká republika patří k zemím, ve kterých jsou rozdíly $\mathrm{v}$ závislosti na vzdělání rodičů nadprůměrné. Pokud analyzujeme tuto závislost pouze v nejmladší kohortě (16-24), jsou v České republice rozdíly ve výsledcích dospělých s vysokoškolským vzděláním a dospělých s nižším než středoškolským vzděláním čtvrté nejvyšší po Slovensku, Velké Británii a Polsku.

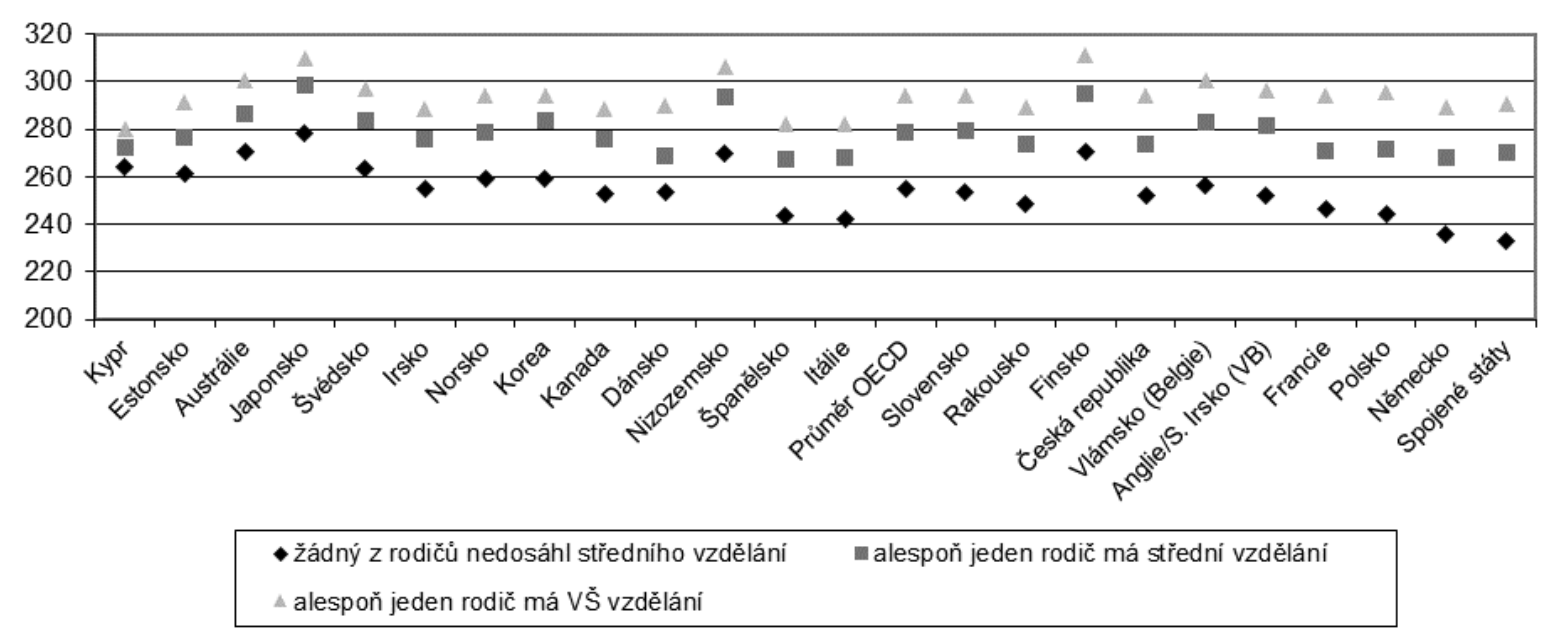

Obrázek 4. Čtenářské kompetence podle vzdělání rodičů. 


\subsection{Kompetence a pohlaví}

Mnoha zemím OECD se $\mathrm{v}$ posledních desetiletích podařilo snížit rozdíly mezi muži a ženami v dosaženém vzdělání, kvalifikaci a pozicí v zaměstnání. Mezinárodní srovnávací výzkum výsledků patnáctiletých žáků PISA ukázal, že dívky dosahují vyšších výsledků ve čtenářské gramotnosti než chlapci a že mají vyšší kariérní aspirace. Současně také platí, že v zemích OECD se terciárního vzdělávání účastní více žen než mužů.

Ve čtenářské gramotnosti dosahují v zemích OECD muži průměrného skóru 274, zatímco ženy 272 . V průměru tak nejsou výsledky mužů a žen příliš odlišné a v mnoha zemích jsou statisticky nevýznamné. V České republice dosahují muži statisticky významně vyššího skóru (muži 276, ženy 272). Jedinou zemí, kde ženy dosahují statisticky významně lepších výsledků než muži, je Polsko.

V numerické gramotnosti jsou rozdíly výraznější: v zemích OECD dosahují muži průměrného skóru 275 , zatímco ženy jen 264 . Ve všech zemích dosahují muži vyššího skóru, nicméně rozdíly mezi zeměmi jsou v tomto ohledu obrovské. Nejnižší (a statisticky nevýznamné) rozdíly mezi muži a ženami jsou v Polsku a na Slovensku: jen dva body. Naopak v Nizozemsku a Německu je to celých 17 bodů. $V$ České republice jsou rozdíly spíše nižší: muži dosahují průměrného skóru 280, ženy 271.

Pokud jde o dovednosti řešení problémů, muži v zemích OECD dosahují průměrného skóru 286, zatímco ženy 280 . Ve všech zemích dosahují muži v této dovednosti vyššího průměrného skóru, rozdíly se ovšem $v$ jednotlivých zemích opět liší. Nejvyšší rozdíly jsou v Rakousku, Velké Británii, Japonsku a Nizozemsku ( 8 až 9 bodů). Česká republika se opět řadí k zemím se spíše menšími rozdíly - muži dosahují průměrného skóru 285, zatímco ženy 281.

Na rozdíly mezi muži a ženami v ČR je zajímavé se podívat v jednotlivých kohortách. Obrázek 5 ukazuje výsledky ve čtenářské gramotnosti. Zde je zřejmé, že ženy dosahují na konci studia lepších výsledků než muži, ve středním věku značně ztrácejí a v pokročilejším věku se rozdíly opět vyrovnávají. 


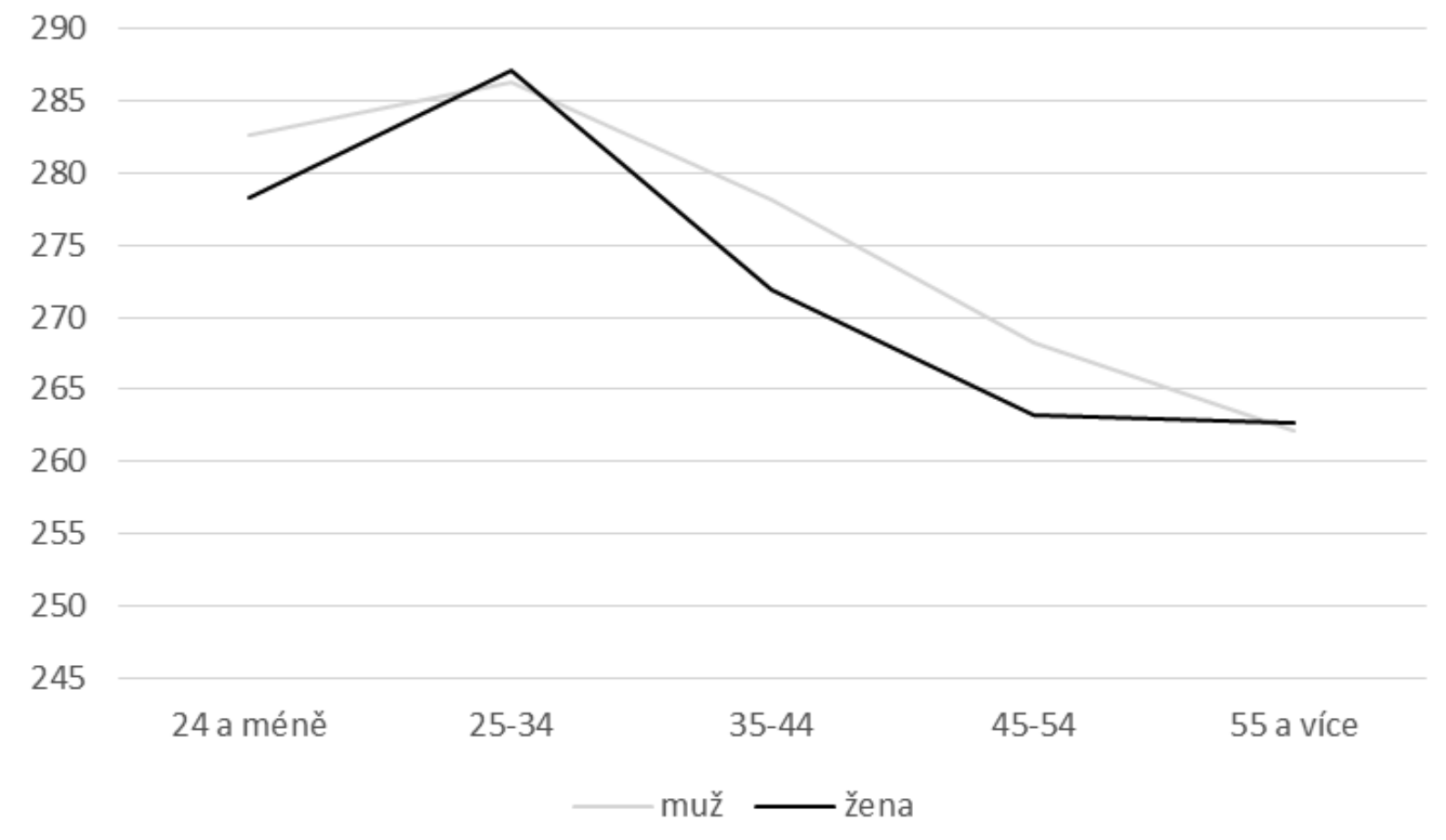

Obrázek 5. Čtenářská gramotnost podle věku a pohlaví.

\subsection{Výsledky středoškoláků a vysokoškoláků}

Velkou předností výzkumu PIAAC je možnost podívat se na výsledky vyšších stupňů vzdělávacího systému, kterou nám žákovské výzkumy neposkytují. Ve výzkumech organizovaných Mezinárodní asociací pro hodnocení výsledků vzdělávání TIMSS a CIVED se objevily pokusy hodnotit žáky na konci středoškolského vzdělávání, které však ztroskotaly na tom, že střední vzdělávání trvá v jednotlivých programech různě dlouho (žáci opouštějí systém v různých ročnících studia) a v jednotlivých zemích ho navštěvují různé podíly populace. Výzkum PIAAC nám umožňuje výsledky absolventů přeci jen do jisté míry posoudit.

V př́padě absolventů vysokých škol si klademe otázku, do jaké míry jsou jejich vědomosti a dovednosti srovnatelné s vědomostmi a dovednostmi vysokoškoláků z jiných zemí, zároveň nás zajímá, jak se v čase mění. Výsledky ukázaly, že skupina mladých českých vysokoškoláků (ve věku 25-34 let) má v mezinárodním srovnání ve všech oblastech mírně nadprůměrné výsledky, a to přesto, že podíl vysokoškoláků v populaci aktuálně odpovídá průměru OECD. Od roku 1998 se nicméně výsledky vysokoškoláků zhoršily, což je 
pravděpodobně zapříčiněno skutečností, že se podíl mladých lidí, kteří nastupují k vysokoškolskému studiu, od roku 1998 významně navýšil (od roku 1989 došlo k trojnásobnému navýšení z 20 \% na téměř 60 \% věkové kohorty), tedy vysokoškolské studium přestalo mít elitní povahu.

V případě středoškoláků by bylo zajímavé provést mezinárodní porovnání vědomostí a dovedností absolventů jednotlivých oborů. To je však obtížně realizovatelné, nebot' se středoškolské obory v jednotlivých zemích značně liší a v datech není informace o tom, jaký obor ten který respondent absolvoval. Tato informace je tedy $\mathrm{k}$ dispozici pouze u českých respondentů. Obrázek 6 ukazuje výsledky absolventů všech tří typů středoškolského studia ve všech oblastech hodnocených výzkumem PIAAC a ve čtenářské gramotnosti ve výzkumu IALS. Rozdíly ve výsledcích absolventů jednotlivých typů studia byly a stále jsou značné. Od roku 1998 se ovšem významně zvýšily rozdíly mezi středním odborným studiem s maturitou a studiem bez maturity.

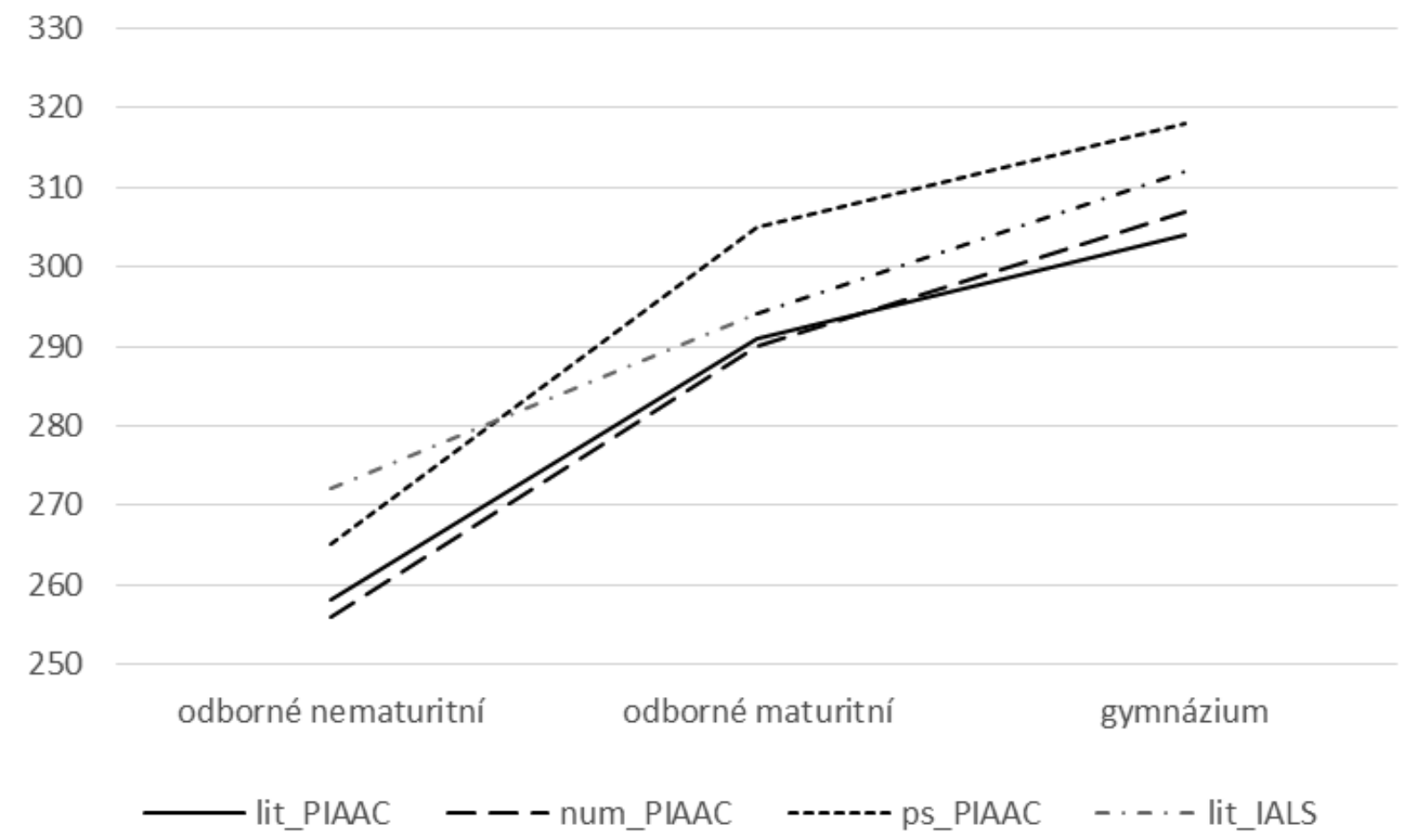

Obrázek 6. Rozdíly mezi absolventy jednotlivých typů středoškolského studia, 1998, 2012. 


\subsection{Neekonomické efekty gramotnosti}

Výzkum PIAAC zkoumal kromě vědomostí a dovedností rovněž několik obecných životních postojů. Dotazoval se respondentů na jejich subjektivní zdravotní stav, na jejich charitativní aktivity, na důvěru k okolí a na víru v to, že mohou ovlivnit společnost, ve které žijí. Výzkum potvrdil poznatky z výzkumů v žákovské populaci, které opakovaně ukázaly v mezinárodním srovnání relativně malou ochotu českých mladých lidí se angažovat ve prospěch druhých. Ve výzkumu PIAAC skončila Česká republika z hlediska četnosti dobrovolnických aktivit na předposledním místě před Španělskem. $82 \%$ dospělých uvedlo, že v minulém roce nevykonali ani jednu dobrovolnickou aktivitu. Relativně nízká byla i víra dospělých $\mathrm{v}$ možnost ovlivnit společnost, ve které žijeme. 85 \% dospělých vyjádřilo souhlas s tím, že člověk může doopravdy důvěrovat jen několika málo lidem a že když si člověk nedá pozor, snadno ho někdo jiný začne využívat. Když se podíváme, jak se liší podíly českých nedůvěřivých $\mathrm{v}$ jednotlivých věkových kohortách, zjištujeme, že se téměř vůbec nemění. Tedy mladí jsou úplně stejně nedůvěřiví jako generace jejich rodičů a prarodičủ. Výzkum nicméně ukázal, že $v$ př́ípadě všech těchto postojů se situace liší v závislosti na úrovni kompetencí. Lidé s vyšší úrovní kompetencí jsou důvěřivější, mají větší víru v to, že mohou ovlivnit společnost, ve které žijí, a jsou více zapojeni v charitativních činnostech.

\section{Závěry a implikace pro vzdělávací politiku}

Jak již bylo zmiňováno $\mathrm{v}$ úvodu, výzkum PIAAC má primárně vypovídat o tom, jak se vědomosti a dovednosti získané v rámci počátečního vzdělávání rozvíjejí v dalším vzdělávání a zejména, jak se uplatňují na trhu práce a v životě dospělých. Ve vztahu k počátečnímu vzdělávání je však také skvělým doplňkem k výzkumům probíhajícím v žákovské populaci, jako je PISA, TIMSS či PIRLS. Za prvé umožňuje zkoumat vědomosti a dovednosti na výstupu ze středního a vysokoškolského vzdělávání v mezinárodním srovnání, což je pro posouzení efektivity vzdělávacího systému důležité, a žádná jiná data $\mathrm{v}$ této oblasti nejsou $\mathrm{k}$ dispozici. OECD se v uplynulých 10 letech pokoušela navrhnout projekt AHELLO, který by prováděl srovnávací výzkumy vysokoškoláků, ale nepodařilo se jej úspěšně realizovat. Pro Českou republiku, která neprovádí žádné vlastní výzkumy vědomostí a dovedností ve středoškolských kohortách, poskytuje PIAAC důležité informace i o výsledcích jednotlivých středoškolských programů. Za druhé na rozdíl od žákovských výzkumů, které přinášejí průřezovou informaci o jedné věkové skupině, 
zachycuje kompetence v celé dospělé populaci a umožňuje tak vyvozovat závěry o dlouhodobých efektech vzdělávacího systému. Mimo jiné těmto efektům pak můžeme přisuzovat různé výsledky jednotlivých věkových skupin.

S výsledky z výzkumů PISA nebo TIMSS se často pracuje jako s definitivním ukazatelem gramotnosti dané země (viz např́klad snaha spočítat vliv výsledků v testech na růst HDP, např́íklad OECD, 2010; Hanushek \& Woessmann, 2011). Výzkum PIAAC ale ukázal, že v 15 letech zdaleka nejsou kompetence definitivně zformovány. Ve většině zemí se vědomosti a dovednosti po 16. roce věku dále rozvíjejí a dosahují svého vrcholu až ve věku kolem 25-44 let. To je zapříčiněno zejména účastí v terciárním vzdělávání. Musíme vzít ale také v potaz to, že míra kompetencí není dána jen vzděláváním, ale mnoha dalšími faktory, především pak uplatněním na pracovním trhu. Jakkoli jsou výsledky testů žáků a studentů důležité, nelze je brát jako př́mý indikátor dovedností populace $\mathrm{v}$ dané zemi (a to ani budoucích kompetencí pro příslušnou věkovou kohortu). Výzkum PIAAC také ukázal, jak problematické může být pracovat pouze s průměry. Podíváme-li se na průměrné výsledky jednotlivých zemí, zjištujeme, že mezi nimi nejsou nějak extrémně velké rozdíly (alespoň pokud jde o vyspělé země). Výzkum PIAAC nicméně odhalil velké rozdíly uvnitř jednotlivých zemí, mezi jednotlivci i skupinami.

Obecně řečeno, výzkum PIAAC potvrdil některé závěry z výzkumů žáků a studentů, jako je PISA a TIMSS (např́iklad míru podmíněnosti kompetencí socioekonomickým statusem). Některá zjištění z těchto výzkumů ovšem umožňuje nahlížet $\mathrm{z}$ poněkud jiné perspektivy. Lze tedy říci, že $\mathrm{v}$ tomto ohledu je výzkum PIAAC jedinečný. Jaké jsou tedy hlavní implikace PIAAC pro vzdělávací politiku v České republice?

Za prvé, pokud budeme hodnotit výzkum jako celek a vezmeme-li v úvahu, že výzkumu se zúčastnily jen opravdu vyspělé země, celkově lze říci, že výsledky české populace nejsou špatné. Nepotvrdila se hypotéza katastrofálního zhoršení v kompetencích, které naznačovaly (resp. jak byly většinově interpretovány) výsledky výzkumů z let 2007 (TIMSS) a 2009 (PISA). Výsledky mladých Češek a Čechů ve věku 16-25 let nebyly vůbec špatné (a právě sem spadá kohorta z výzkumů TIMSS 2007 a PISA 2009). Např́́klad v numerické gramotnosti v této věkové skupině dosáhli lepších výsledků pouze mladí lidé z Nizozemska a Finska. (Je však pravda, že výsledky jsou zde velmi vyrovnané.) Relativně dobré výsledky české dospívající mládeže následně potvrdil i výzkum PISA 2012 (Palečková \& Tomášek, 2013). 
Jak již bylo uvedeno výše, $v$ řadě aspektů PIAAC podporuje zjištění z výzkumů v žákovské populaci. Rozdíly v kompetencích nejsou v České republice příliš vysoké, jsou však více než jinde podmíněny sociálním prostředím. Je to dáno tím, že na úrovni základního a středního školství stále nedokážeme účinně kompenzovat znevýhodnění, které si žáci do školy přinášejí z rodiny. Prostřednictvím silně diferencovaného systému, kde se od sebe jednotlivé programy výrazně odlišují z hlediska kognitivní náročnosti i z hlediska složení žáků, kteří je navštěvují, je dokonce dále posilujeme. I výzkum PIAAC potvrdil velké rozdíly $\mathrm{v}$ kompetencích absolventů různých středoškolských programů. Česká republika se může pochlubit malým zastoupením občanů s velmi nízkou úrovní dovedností i malým rozdílem mezi těmi nejhoršími a nejlepšími. To však znamená určitou absenci skupiny s vysoce nadprůměrnými dovednostmi. Na úrovni vysokých škol neexistuje dostatečná nabídka opravdu náročných „výběrových“ škol pro ty opravdu nejlepší. V tomto ohledu to je u nás zcela odlišná situace než například ve Finsku. Finský vzdělávací systém klade velký důraz na sjednocení vzdělávacích šancí na úrovni povinného a středního vzdělávání, ale vysoké školství je velice konkurenční.

Pokud porovnáme výsledky ve čtenářské gramotnosti ve výzkumu PIAAC s výzkumem IALS, který proběhl v ČR v roce 1998, můžeme říci, že naše celkové dovednosti zůstaly stejné - tedy nedošlo ke statisticky významnému zlepšení ani zhoršení. Velmi výrazně se ale proměnilo rozložení těchto dovedností v populaci. Např́íklad podobně jako v jiných zemích došlo ke zhoršení nejmladších věkových skupin a naopak si polepšily starší věkové skupiny. To může mít celou řadu příčin. Může jít o delší ekonomickou aktivitu a aktivnější „,seniorský“ život. Může jít ale také o to, že získávání dovedností se již tolik nekoncentruje do povinného školního vzdělávání, ale je více $\mathrm{v}$ čase rozloženo.

Výzkum PIAAC přispěl v ČR k získání nových poznatků, zároveň ale otevřel i některé nové otázky - např́́klad propad ve střední generaci, který je v mezinárodním srovnání vysoký a nelze jej jednoduše vysvětlit. Tak jako jinde ve světě i u nás platí, že lepších výsledků dosahují mladí lidé, s vyšším vzděláním, kteří pocházejí z lepšího rodinného zázemí. V porovnání s ostatními zeměmi dosahuje výborných výsledků věková skupina 25-34, naopak ve věkové skupině 35-54 let se ve čtenářské gramotnosti propadáme do podprůměru. Zvlášt' markantní je propad žen v těchto věkových kohortách. Věková skupina 55-65 let je pak zase výrazně nadprůměrná. Jednu z hlavních př́ičin lze pravděpodobně hledat v zastoupení středoškoláků a vysokoškoláků 
v jednotlivých zemích. Země prošly různým vývojem vzdělávacích systémů. Česká republika měla náskok v počtu lidí s dokončeným středoškolským vzděláním. To může být jeden z hlavních důvodů dobrých výsledků té nejstarší generace. Naopak expanze přístupu k vysokoškolskému vzdělání u nás nastala až později než $\mathrm{v}$ mnoha jiných zemích. To může být jednou z prŕčin slabších výsledků té střední generace a naopak výborných výsledků věkové kohorty 25-34. Ve vztahu k výsledkům žen jsou zmiňovány možné obtíže při slad’ování pracovního a rodinného života. Česká republika se vyznačuje v mezinárodním srovnání nadstandardně dlouhou rodičovskou dovolenou, která je zajišt'ována $v$ drtivé většině případů ženami. I výzkum PIAAC ukázal, že v ČR máme v mezinárodním srovnání vysoký podíl ekonomicky neaktivních vzdělaných mladých žen.

Výzkum PIAAC ukázal, že kompetence výrazně souvisejí s dosaženým vzděláním. Celkové výsledky zemí jsou do značné míry ovlivněny dobou, kdy došlo $\mathrm{k}$ otevření terciárního vzdělávání široké populaci. V této souvislosti je velmi zajímavé pozorovat rozdíly mezi nejstarší a nejmladší věkovou skupinou v jednotlivých zemích. Zatímco např́iklad v Anglii žádný rozdíl prakticky neexistuje, $\mathrm{v}$ Jižní Koreji je naprosto zásadní. Míra dosaženého vzdělání je jedním z hlavních faktorů ovlivňujících míru kompetencí. Kompetence jsou ale formovány celou řadou dalších faktorủ. Rozhodně nejde jen o vzdělávací politiku, ale vliv má i politika zaměstnanosti, rodinná politika, sociální politika atd. Vzdělávací politika by měla být s těmito politikami těsně provázána.

Výzkum PIAAC může významně promluvit do debaty, která se v České republice vede o budoucnosti středního vzdělávání. Dlouhodobý záměr rozvoje vzdělávací soustavy pro roky 2011-2015 obsahuje cíl zachovat podíl absolventů středního vzdělání bez maturity na minimálně $32 \%$. Výsledky výzkumu však ukazují, že absolventi středního studia bez maturity mají nízkou úroveň kompetencí nejen ve srovnání s jinými typy středoškolského studia $\mathrm{v}$ ČR, ale i ve srovnání s podobně vzdělanými mladými lidmi v jiných zemích. Nízká úroveň kompetencí bude pravděpodobně jedním z faktorů, který zapříčiňuje vysokou nezaměstnanost absolventů středních odborných učilišt'. Výsledky napovídají, že důležitým krokem vzdělávací politiky v této oblasti by měla být modifikace vzdělávacích programů tak, aby se žákům v těchto oborech dostávalo kvalitnějšího vzdělání, které jim bude na pracovním trhu užitečnější. Tvůrci vzdělávacích politik by neměli nutit mladé lidi k volbě, která pro ně je z hlediska budoucího uplatnění nevýhodná. 
Již dlouho je známo, že vzdělávání má mimo pozitivních ekonomických efektů (jako jsou například vyšší př́ijmy a nižší nezaměstnanost) také celou řadu neekonomických přínosů. Výzkum PIAAC ukázal, že ve všech zemích, včetně České republiky, lidé s vyššími kompetencemi se cítí zdravější a také se více věnují dobrovolnické práci. Výzkum také ukázal, že lidé s vyššími kompetencemi více důvěřují ostatním lidem, což je zvláště důležité v České republice. Výzkum PIAAC totiž také ukázal, že míra této důvěry je u nás velmi nízká, což se negativně projevuje ve všech stránkách života. Je ovšem pravdou, že doposud přesně nevíme, jakými mechanismy vyšší kompetence vedou k těmto pozitivním přínosům. Každopádně platí, že investice do kompetencí se vyplácí nejenom z ekonomického hlediska.

V rámci tohoto přehledového článku bylo možné zmínit jen malou část zjištění, která výzkum PIAAC přinesl, a nebylo možno se věnovat jejich detailní reflexi. Mnohá další zjištění a jejich podrobnější rozbor lze nalézt v jiných publikacích (OECD, 2013a; Straková \& Veselý, 2013; Průcha, 2014).Zároveň je ovšem vhodné zmínit, že data PIAAC stále ještě nebyla zcela „vytěžena“. Pro zájemce jsou na webových stránkách výzkumu PIAAC (http://www.oecd.org/site/piaac/) přístupná i nesmírně bohatá zdrojová data ze všech zúčastněných zemí, která mohou být použita ke zkoumání celé řady doposud nezodpovězených otázek. Na webových stránkách výzkumu je také k dispozici aplikace Data Explorer, která umožňuje počítat jednoduché mezinárodní komparace. Zájemce o česká data odkazujeme na české stránky (www.piaac.cz), kde je k dispozici řada informací o projektu v českém jazyce a také česká verze použitého dotazníku.

\section{Literatura}

Hanushek, E. A., \& Woessmann, L. (2011). How much do educational outcomes matter in OECD countries? Economic Policy, 26(67), 427-491.

Koenig, J. A. (Ed.). (2011). Assessing 21st century skills. Dostupné z http://www.nap.edu/catalog. php?record_id=13215

OECD. (2010). The high cost of low educational performance. The long-run economic impact of improving PISA outcomes. Paris: OECD.

OECD (2013a). OECD skills outlook 2013. First results from the Survey of Adult Skills. Paris: OECD.

OECD (2013b). PISA 2012 Frameworks - Mathematics, Problem Solving and Financial Literacy. Paris: OECD.

OECD. (2013c). Technical report of the Survey of Adult Skills (PIAAC). Paris: OECD.

Palečková, J., Tomášek, V., Basl, J., Blažek, R., \& Boudová, S. (2013). Hlavní zjištění PISA 2012. Matematická gramotnost patnáctiletých žáků. Praha: ČŠI.

Průcha, J. (2014). Vzdělanost Čechů a výzvy pro teorii pedagogiky. Pedagogická orientace, 24(2), 275-281. 
Rychen, D. S., \& Salganik, L. H. (2001). Defining and selecting key competencies. Göttingen: Hogrefe \& Huber Publishers.

Straková, J., \& Veselý, A. (Eds.). (2013). Předpoklady úspěchu v práci a v životě. Výsledky mezinárodního výzkumu dospělých OECD PIAAC. Praha: DZS.

\title{
Autoři
}

RNDr. Jana Straková, Ph.D., Univerzita Karlova v Praze, Pedagogická fakulta, Ústav výzkumu a rozvoje vzdělávání, Myslíkova 7, 11000 Praha 1, e-mail: jana.strakova@pedf.cuni.cz

Doc. PhDr. Arnošt Veselý, Ph.D., Univerzita Karlova v Praze, Fakulta sociálních věd, Institut sociologických studií, U Kříže 8, 15800 Praha 5, e-mail: veselya@fsv.cuni.cz

\section{Adult skills surveys PIAAC: Basic findings and implications for educational policy}

\begin{abstract}
The aim of this review article is to describe Programme for the International Assessment of Adult Competencies (PIAAC), summarize the basic findings and discuss possible implications for educational policy in the Czech Republic. We also discuss to what extent results from PIAAC complement empirical evidence from PISA, TIMSS and similar students' assessments. We ask whether (and what) PIAAC reveals beyond these research projects. The article starts with a description of PIAAC methodology and it basic features. Second, we describe the results of the Czech population vis-à-vis other countries involved in the assessment. Third, we focus upon several core findings of PIAAC. In the final part we discuss implications of the findings for educational policy in the Czech Republic. PIAAC has confirmed several findings revealed in PISA and TIMSS, e.g. strong impact of socio-economic background upon students' performance. Other findings, however, rather contradicted PISA and TIMSS. For instance, it was found that the results of Czechs aged 16-25 (which were under the international average in PISA and TIMSS) are above the average. PIAAC has been found to be unique and indispensable source of information, complementing students' assessments. Although results in PISA and TIMSS are usually taken as a final and definitive indicator of the country's stock of human capital, PIAAC has clearly demonstrated that at the age of 15 the competencies are far from definitely formed.
\end{abstract}

Keywords: PIAAC, adult literacy, educational policy, Czech Republic 